\title{
Molecular biology: suffering from shock
}

THE recent meeting of molecular biologists convened by COGENE. the Committee on Genetic Experimentation of the International Council of Scientific Unions, was an instructive affair--but not in the way the organisers intended. The lesson came in their treatment of the press. First the meeting was open; then it was closed to journalists. Then it was open to three journalists picked by the Association of British Science Writers, but the proceedings were to be 'off the record'. Then at the last moment all restrictions were lifted.

To be fair. the organisers of the meeting-COGENE and the Royal Society-admitted they had made a mistake; they were under pressure, it seemed, from biologists who had had bad experiences with the US press. And the press is certainly no angel. But the meeting's attitude to it was symptomatic of a deeper malaise: that despite the promise of the 'Berg letter' (Genesis, someone called it) which launched molecular biology into politics. biologists have failed to grasp the nettle of their relationship to the public. The press, after all, represents all the fears and frustrations of its readers: it is the public writ in 48 point bold caps.

However the molecular biologists-if the COGENE meeting was a guide- now feel that their subject has no right to be in the public arena at all. The Berg letter called for a pause to assess the risks of the recombinant DNA technique, we have had the pause, and the risks are found to be negligible. So why don't the NIH, and GMAG, and the other regulatory agencies just go away? That was the strong mood of the meeting. "We want to achieve reentry," someone said. But as Sir Frederick Warner, one of the assessors at the Windscale inquiry into nuclear reprocessing. told the meeting, the three great fears have been raised in the public mind: carcinogenesis, mutagenesis, and teratogenesis. The public won't go away. Reentry into the womb is no longer possible, even if it seems rational.

Paul Berg's two revolutionary impacts on molecular biology the recombinant DNA technique itself. and (with the other 10) the Berg letter-have left molecular biologists in a state of shock. Within six years they have found an immensely promising research technique; they have entered biotechnology. with undreamt-of profits to be made: and they have entered politics with their perfectly rational whistle-blowing over conjectural risks. All this happened at just the time when a new breed of radical scientists was searching for something to cut its teeth on. and when the regulation of science and technology was becoming fashionable among governments. So no wonder the biologists are reeling.

No doubt the organisers of the COGENE meeting intended that it should come to terms with this new climate.
But it only reacted to it. Four major issues facing molecular biology were either not addressed or left unresolved. First, what really are the arguments that the risks are negligible? Although there were interesting talks-such as that of Walter Bodmer on species barriers - which were relevant to the question, there was no scientific debate of the matter. Where were the critics-and there are scientific critics, with genuine arguments-to bring matters to a head? To the outside observer the view that risks are negligible went through on the nod. If the biologists are to face the public they must do better than communicate a mood; they must construct arguments that are for more than internal consumption. To do that they must embrace their heretics, not spit at them.

Second, there was not a minute of discussion of the new procedure for risk assessment devised by Sidney Brenner and recently adopted by Britain's Genetic Manipulation Advisory Group. Confounding its critics who complain that biological knowledge is to patchy for it to work, this method is already in use in GMAG, and has resulted in the down-grading of a number of experiments. If it is false, it should be exposed; if it is correct, being simple and logical it could be the basis of communicating the biologists' new mood to the public.

Third, if there was no scientific debate, neither was there political debate, despite the fact that it is clear that the biologists' re-entry must be a political one. The most moderate voices, such as that of Mark Richmond, showing sensitivity to politics and public opinion, sounded radical against the growls of the rednecks, and were submerged.

Fourth and last, the role of molecular biology in technology, where recombinant DNA is the microprocessor chip of the pharmaceutical industry, was dealt with only at the level of bioengineering and gee-whizzery. And yet here is a technique which has already generated a new social world for the biologist, who is becoming suspicious of his colleague's motives (does he want my enzyme for profit or for science?) and hungry for a new kind of success. Is that not a significant develcpment? Why was it not a subject for debate? Further, what impact will this technique have on medicine and agriculture? Should it be left to the few secretive new firms that are engaged on it. or do we have a chance to create a humane and democratic technology? These questions were ignored.

Molecular biologists are firmly in politics now, and it is totally irrational to ignore the fact. Nuclear physicists should envy them: for the physicists generated their technology first, became committed to it. and burnt their political fingers later. The biologists have the opportunity to learn their politics first, and grow with it. They should not miss the opportunity. 